\title{
Political instability and stock market returns: Evidence from OECD countries
}

\author{
Dimitrios Asteriou $^{*} \cdot$ Antonios Sarantidis $^{2}$ \\ ${ }^{1}$ Oxford Brookes University, UK \\ ${ }^{2}$ Hellenic Open University, Greece
}

Received: 31 July 2016

Revised: 7 October 2016

Accepted: 22 October 2016

\begin{abstract}
This paper examines the relationship between political instability and stock market returns using quarterly time series data from 1993 to 2013. In this paper, stock market returns are defined as the returns of the general stock market index and banking index for 18 OECD countries. Five different political instability indicators are constructed in order to measure political uncertainty. The empirical part utilizes the EFA, PCA and GARCH-M methodologies. The findings indicate a direct and an indirect impact between the PI indicators and the returns of the Banking Index and the Overall Stock Market Index. The research contributes to the literature by providing empirical evidence to policy makers on the effects that political instability has on stock markets.
\end{abstract}

Keywords: political instability; stock market returns; GARCH-M.

JEL Classification Codes: C32, C58, G10, G12

\section{Introduction}

The impact of political instability (PI) on financial market performance has been a significant topic of debate over the last years. The relationship between PI and stock markets has been widely examined in the empirical literature, especially after the recent financial crisis. Diamonte et al. (1996) and Lehkonen and Heimonen (2015), show that a reduction in political risk could lead to higher portfolio and stock returns. Huang et al. (2015) find a positive relationship between international political risks and government bond yields. Smales (2014) uses the Australian federal elections as a proxy for political uncertainty. He shows evidence that this political uncertainty proxy has a significant impact on the uncertainty of the financial markets. Li and Born (2006) and Gemmill (1992) also provide evidence of a strong relationship between the elections and the financial markets. Addoum and Kumar (2016) examine the effects of political climate changes on financial market outcomes. The number of elections, the transition

\footnotetext{
* Corresponding author. E-mail: dasteriou@brookes.ac.uk.
}

Citation: Asteriou, D. and Sarantidis, A. (2016) Political instability and stock market returns: Evidence from OECD countries, Economics and Business Letters, 5(4), 113-124. 
between the power of political parties and the political alignment index (PAI) are used as PI variables. They show that the investor demand is influenced by the shifts in the political climate. Moreover, these changes affect the returns of firms and industries that are politically sensitive. Some other studies use as PI variables or as a part of those, terrorism actions and events. That studies shows evidence of a strong negative relationship between terrorism actions/events and financial markets (Jackson, 2008; Chesney at al., 2011).

While the theoretical part of PI has been widely studied the empirical part seems to have space for further research. The multidimensionality of PI is a topic that has not been studied enough. There are only a few studies that examine this issue. For example, Bussiere and Mulder (1999) used various indicators that quantify PI during the crisis episodes of 1994 and 1997 in order to examine the effects of PI on economic vulnerability. Additionally, Jong-A-Pin (2009) examined the impact of 25 different PI indicators on economic growth. However the first study is largely outdated, while Jong-A-Pin's (2009) study - as most PI related studies - provides similar measures for a large set of countries that are being examined all together in a panel. We believe that PI is a very complex issue to be examined in a way that aggregates data for many countries with different characteristics, both market/economy related but also political environment related. Therefore, in this paper we are trying to fill this gap by examining the multidimensionality of PI on a country level with time series data that allow for different PI indicators for each country. We aim to reanalyze the notion of PI and to estimate its impact on the returns and the variance (volatility) of the banking and general stock market indices. In order to achieve this, we construct five different PI indicators by using 27 different PI variables. These variables are mentioned in the corresponding empirical literature of political uncertainty. We apply Exploratory Factor Analysis (hereafter EFA), Principal Components Analysis (hereafter PCA) and the econometric method of GARCH-M, in order to examine for possible negative effects between PI, banking stock returns and overall stock market returns. We use quarterly time series data for 18 OECD countries from 1993 to 2013. By using time series data we can test for possible PI effects on the conditional variance of the banking stock returns and the overall stock market returns. Our results - contrary to most studies that simply quantify the negative effects of PI - show that not all political PI indicators have the same importance with regards to stock market and banking sector returns and volatilities. In fact while in general we find a direct/indirect negative impact of the five PI indicators on the banking and general stock market returns/on the variance of banking and general stock market returns, some PI indicators are non-significant, while some others suggest the possibility of a positive effect coming from some PI indicators. Finally, we also observe that there are different effects from different PI indicators to market stock returns and banking returns which makes the issue even more complicated. Therefore, from this more analytical, country focused time series approach, the current research contributes to the literature by providing to policy makers a deeper understanding of the possible effects that PI has on stock markets producing some new results.

The rest of the paper is organized as follows. Section 2 presents the proposed methodology. Section 3 describes the dataset, and Section 4 reports and analyzes the empirical results. Finally, Section 5 concludes.

\section{Methodology}

For the empirical part of this paper, we first employ the EFA. This statistical technique is used in order to reduce a large set of variables into a smaller set of variables and to indentify the structure of their relationship (Fabriger and Wegener, 2011). Next, we use the EFA in order to sort the 27 PI variables and to obtain for each country the most significant variables according to their loadings. Furthermore, we determine the PI indicators (hereafter PI indicators) and specify the variables by which each indicator consists. After this variable separation we employ 
the $P C A$ in order to construct the PI indicators from the variables obtained from the EFA procedure. These new indicators are constructed from an initial set of variables $\left(X_{j}, j=\right.$ $1,2, \ldots, k)$. The $P C A$ transforms the data in that way that the greatest variance comes to lie on the first principal component and the second greatest variance on the second principal component. The same procedure is followed for the third greatest variance, and so on.

Before proceeding with our methodology, we test for possible correlations between the PI indicators. The coefficients show us how strongly pairs of indicators are related. After this procedure some of the indicators are excluded from the further analysis of specific countries because of their high correlation. For the main empirical part we focus at the uncertainty that PI indicators have. Thus we look at the conditional variance of the output. Moreover, if we want to allow uncertainty to affect stock market or banking stock returns directly, then we estimate the GARCH-M model. This model allows us to test if the uncertainty in the returns could affect the returns of the stock market and banking indices and if the PI indicators could affect the returns of the indices separately. The econometric model of GARCH-M (1,1) (Engle et al., 1987; Enders, 1995) takes the following form:

$$
\begin{gathered}
\Delta \log \left(Y_{t}\right)=a_{0}+\sum_{i=0}^{p} a_{i} \Delta \log \left(y_{t-1}\right)+\gamma h_{t}+e_{t} \\
e_{t} \sim N\left(0, h_{t}\right) \\
h_{t}=b_{1} e_{t-1}^{2}+b_{2} h_{t-1}+\sum_{i=1}^{p} b_{i} X_{t-1}
\end{gathered}
$$

As in the GARCH $(1,1)$ model above, the overall stock market returns and banking stock returns are modeled as an AR (1) process, including the overall stock market returns and banking stock returns and the variance of the error term. The variance of the error term $\left(h_{t}\right)$ is an equation of the lagged variance, the lagged squared residuals and the PI indicators $\left(X_{t-1}\right)$.

\section{Data}

Data on the economic and political variables are collected for 18 OECD countries; the time period covers the years from 1993-2013, using quarterly time series data. The countries included in the analysis are Australia, Austria, Belgium, Canada, Denmark, Finland, France, Germany, Greece, Ireland, Japan, Italy, the Netherlands, Portugal, Spain, Sweden, United Kingdom and the United States.

We test the hypothesis that PI affects stock returns by estimating time series regressions for the overall stock market index (general index of each country) and the banking index. Data on the two stock market indices are obtained from Thompson Reuters Datastream. Summary statistics and unit root tests are presented in Table 1 and 2 for the prices and returns of the banking index and the overall stock market index.

The unit root tests in Table 1 and 2 show that the prices of the indices are non-stationary; i.e. they contain a unit root. In contrast to the prices, the returns of the indices are stationary and do not contain a unit root (the null of unit root is clearly rejected in all cases).

The innovation in this paper is that we are using 27 different PI indicators that are mentioned in the literature in order to construct five different PI indicators. The aforementioned variables are presented in Table 3. 
Table 1. Summary statistics and unit root tests for Banking Index/Returns.

\begin{tabular}{|c|c|c|c|c|c|c|}
\hline \multirow[b]{2}{*}{ Countries } & \multicolumn{3}{|c|}{ Banking Index-Prices } & \multicolumn{3}{|c|}{ Banking Index-Returns } \\
\hline & $\begin{array}{c}\text { Mean } \\
\text { (St. Dev.) }\end{array}$ & $\begin{array}{l}\text { Min } \\
\text { Max } \\
\end{array}$ & $\begin{array}{l}\text { ADF-stat. } \\
\text { (p-value) }\end{array}$ & $\begin{array}{c}\text { Mean } \\
\text { (St. Dev.) }\end{array}$ & $\begin{array}{l}\text { Min } \\
\text { Max }\end{array}$ & $\begin{array}{l}\text { ADF-stat } \\
\text { (p-value) }\end{array}$ \\
\hline Australia & $\begin{array}{l}1.326,45 \\
(560.36)\end{array}$ & $\begin{array}{c}379,43 \\
2.322,47\end{array}$ & $\begin{array}{c}-0,32 \\
(0.37)\end{array}$ & $\begin{array}{c}2,24 \\
(8.16)\end{array}$ & $\begin{array}{l}-23,82 \\
25,25\end{array}$ & $\begin{array}{c}-4,43 \\
(0.00)\end{array}$ \\
\hline Austria & $\begin{array}{c}310,94 \\
(202.78)\end{array}$ & $\begin{array}{l}117,46 \\
896,27\end{array}$ & $\begin{array}{l}-0,53 \\
(0.29)\end{array}$ & $\begin{array}{c}0,93 \\
(15.88)\end{array}$ & $\begin{array}{c}-53,96 \\
42,44\end{array}$ & $\begin{array}{l}-5,04 \\
(0.00)\end{array}$ \\
\hline Belgium & $\begin{array}{c}835,78 \\
(481.87)\end{array}$ & $\begin{array}{c}92,92 \\
1.787,19\end{array}$ & $\begin{array}{c}0,81 \\
(0.79)\end{array}$ & $\begin{array}{c}-0,76 \\
(22.49)\end{array}$ & $\begin{array}{c}-110,22 \\
49,67\end{array}$ & $\begin{array}{c}-3,83 \\
0,0001\end{array}$ \\
\hline Canada & $\begin{array}{l}1.450,79 \\
(765.93)\end{array}$ & $\begin{array}{c}300,19 \\
2.705,25\end{array}$ & & $\begin{array}{c}2,75 \\
(9.60)\end{array}$ & $\begin{array}{c}-33,22 \\
25,66\end{array}$ & $\begin{array}{l}-5,98 \\
(0.00)\end{array}$ \\
\hline Denmark & $\begin{array}{c}1.790,44 \\
(1073.63) \\
\end{array}$ & $\begin{array}{c}425,74 \\
4.596,88\end{array}$ & $\begin{array}{l}-0,71 \\
(0.24)\end{array}$ & $\begin{array}{c}1,90 \\
(17.88)\end{array}$ & $\begin{array}{l}-77,72 \\
72,83 \\
\end{array}$ & $\begin{array}{l}-5,89 \\
(0.00)\end{array}$ \\
\hline Finland & $\begin{array}{c}175,40 \\
(102.76)\end{array}$ & $\begin{array}{c}16,99 \\
377,14\end{array}$ & $\begin{array}{c}0,17 \\
(0.57)\end{array}$ & $\begin{array}{c}3,83 \\
(15.98)\end{array}$ & $\begin{array}{l}-51,93 \\
53,29 \\
\end{array}$ & $\begin{array}{l}-3,81 \\
(0.00)\end{array}$ \\
\hline France & $\begin{array}{c}460,60 \\
(244.88)\end{array}$ & $\begin{array}{c}158,70 \\
1.054,48\end{array}$ & & $\begin{array}{c}0,78 \\
(19.01)\end{array}$ & $\begin{array}{l}-66,68 \\
54,87\end{array}$ & $\begin{array}{l}-4,92 \\
(0.00)\end{array}$ \\
\hline Germany & $\begin{array}{c}322,20 \\
(137.02)\end{array}$ & $\begin{array}{l}146,37 \\
673,94\end{array}$ & $\begin{array}{c}0,14 \\
(0.56)\end{array}$ & $\begin{array}{c}-0,22 \\
(17.15)\end{array}$ & $\begin{array}{l}-54,17 \\
46,49 \\
\end{array}$ & $\begin{array}{l}-4,27 \\
(0.00)\end{array}$ \\
\hline Greece & $\begin{array}{l}1.282,15 \\
(958.22)\end{array}$ & $\begin{array}{c}59,23 \\
3.377,96\end{array}$ & $\begin{array}{c}0,29 \\
(0.61)\end{array}$ & $\begin{array}{c}-2,00 \\
(23.26)\end{array}$ & $\begin{array}{c}-75,04 \\
52,73\end{array}$ & $\begin{array}{c}-3,26 \\
0,0006\end{array}$ \\
\hline Ireland & $\begin{array}{c}2.788,69 \\
(2231.43)\end{array}$ & $\begin{array}{c}48,89 \\
8.057,36\end{array}$ & $\begin{array}{c}0,66 \\
(0.75)\end{array}$ & $\begin{array}{c}-2,50 \\
(30.29)\end{array}$ & $\begin{array}{c}-175,69 \\
62,41\end{array}$ & $\begin{array}{l}-4,01 \\
(0.00)\end{array}$ \\
\hline Italy & $\begin{array}{l}1.462,02 \\
(719.79)\end{array}$ & $\begin{array}{c}431,24 \\
2.945,44\end{array}$ & $\begin{array}{c}0,24 \\
(0.59)\end{array}$ & $\begin{array}{c}-0,36 \\
(14.92)\end{array}$ & $\begin{array}{c}-44,24 \\
51,38\end{array}$ & $\begin{array}{l}-4,55 \\
(0.00)\end{array}$ \\
\hline Japan & $\begin{array}{c}322,20 \\
(175.65)\end{array}$ & $\begin{array}{c}94,43 \\
691,77\end{array}$ & $\begin{array}{l}-0,64 \\
(0.26)\end{array}$ & $\begin{array}{c}-1,88 \\
(14.07)\end{array}$ & $\begin{array}{c}-39,58 \\
35,45\end{array}$ & $\begin{array}{l}-5,12 \\
(0.00)\end{array}$ \\
\hline Netherlands & $\begin{array}{c}2.160,10 \\
(1384.15)\end{array}$ & $\begin{array}{c}117,65 \\
4.695,06\end{array}$ & $\begin{array}{c}0,64 \\
(0.74)\end{array}$ & $\begin{array}{c}-2,59 \\
(21.89)\end{array}$ & $\begin{array}{c}-141,57 \\
37,74\end{array}$ & $\begin{array}{l}-3,03 \\
(0.00)\end{array}$ \\
\hline Portugal & $\begin{array}{l}145,09 \\
(72.75)\end{array}$ & $\begin{array}{c}17,84 \\
345,51\end{array}$ & $\begin{array}{c}0,52 \\
(0.69)\end{array}$ & $\begin{array}{l}-1,30 \\
(16.40)\end{array}$ & $\begin{array}{c}-45,32 \\
50,90\end{array}$ & $\begin{array}{l}-3,71 \\
(0.00)\end{array}$ \\
\hline Spain & $\begin{array}{c}283,77 \\
(128.28)\end{array}$ & $\begin{array}{c}72,41 \\
544,52\end{array}$ & $\begin{array}{l}-0,45 \\
(0.33)\end{array}$ & $\begin{array}{c}1,36 \\
(15.33)\end{array}$ & $\begin{array}{c}-53,84 \\
43,50\end{array}$ & $\begin{array}{l}-5,00 \\
(0.00)\end{array}$ \\
\hline Sweden & $\begin{array}{l}1.642,08 \\
(774.37)\end{array}$ & $\begin{array}{c}94,42 \\
3.210,01\end{array}$ & $\begin{array}{l}-0,96 \\
(0.17)\end{array}$ & $\begin{array}{c}4,06 \\
(16.36)\end{array}$ & $\begin{array}{r}-41,52 \\
64,81 \\
\end{array}$ & $\begin{array}{l}-4,72 \\
(0.00)\end{array}$ \\
\hline UK & $\begin{array}{c}5.555,80 \\
(2303.04)\end{array}$ & $\begin{array}{l}1.720,19 \\
9.476,01\end{array}$ & $\begin{array}{l}-0,55 \\
(0.29)\end{array}$ & $\begin{array}{c}1,02 \\
(12.28)\end{array}$ & $\begin{array}{l}-28,63 \\
34,00\end{array}$ & $\begin{array}{l}-4,33 \\
(0.00)\end{array}$ \\
\hline US & $\begin{array}{r}235,85 \\
(96.74) \\
\end{array}$ & $\begin{array}{c}75,71 \\
407,26 \\
\end{array}$ & $\begin{array}{c}0,02 \\
(0.51) \\
\end{array}$ & $\begin{array}{c}0,52 \\
(13.44) \\
\end{array}$ & $\begin{array}{c}-59,69 \\
34,58 \\
\end{array}$ & $\begin{array}{c}-4,89 \\
(0.00) \\
\end{array}$ \\
\hline
\end{tabular}

We used the EFA method to sort these variables and then the PCA method in order to construct the five factor variables for our sample. These five PI indicators are named CORR, which contains variables that are closely related with corruption; ELECT, which contains variables that are closely related with elections and the electoral system; $G O V$, which contains variables that are closely related to the government; RIOT, which contains variables that are closely related to riots; and TERROR, which contains variables that are closely related to terrorism. For Austria and Germany no data were available for the TERROR indicator and for Finland for the RIOT indicator, respectively. The Table A1 in the Appendix A gives information about the components for each country by which each PI indicator consist. 
Table 2. Summary statistics and unit root tests for General Stock Market Index/Returns.

\begin{tabular}{|c|c|c|c|c|c|c|}
\hline \multirow[b]{2}{*}{ Countries } & \multicolumn{3}{|c|}{ General Stock Market Index-Prices } & \multicolumn{3}{|c|}{ General Stock Market Index-Returns } \\
\hline & $\begin{array}{c}\text { Mean } \\
\text { (St. Dev.) }\end{array}$ & $\begin{array}{l}\text { Min } \\
\text { Max }\end{array}$ & $\begin{array}{l}\text { ADF-stat. } \\
\text { (p-value) }\end{array}$ & $\begin{array}{c}\text { Mean } \\
\text { (St. Dev.) }\end{array}$ & $\begin{array}{l}\text { Min } \\
\text { Max }\end{array}$ & $\begin{array}{l}\text { ADF-stat } \\
\text { (p-value) }\end{array}$ \\
\hline \multirow{2}{*}{ Australia } & $3.593,00$ & $1.794,00$ & $-0,62$ & 1,31 & $-33,68$ & $-4,93$ \\
\hline & (1199.34) & $6.432,80$ & $(0.27)$ & (6.97) & 16,47 & $(0.00)^{*}$ \\
\hline \multirow{2}{*}{ Austria } & $1.952,55$ & 730,96 & $-0,46$ & 1,53 & $-43,18$ & $-4,53$ \\
\hline & $(1111.25)$ & $4.971,37$ & $(0.32)$ & (12.46) & 25,21 & $(0.00)^{*}$ \\
\hline \multirow{2}{*}{ Belgium } & $2.563,72$ & $1.127,02$ & $-0,28$ & 1,00 & $-32,49$ & $-3,35$ \\
\hline & $(843.06)$ & $4.591,71$ & $(0.39)$ & (10.42) & 24,92 & $(0.00)^{*}$ \\
\hline \multirow{2}{*}{ Canada } & $8.727,21$ & $3.305,50$ & $-0,78$ & 1,68 & $-33,10$ & $-5,16$ \\
\hline & $(3176.17)$ & $14.625,00$ & $(0.22)$ & $(8.27)$ & 15,60 & $(0.00)^{*}$ \\
\hline \multirow{2}{*}{ Denmark } & 280,66 & 82,12 & 0,09 & 2,39 & $-45,89$ & $-5,19$ \\
\hline & $(127.34)$ & 556,56 & $(0.54)$ & (10.69 & 25,19 & $(0.00)^{*}$ \\
\hline \multirow{2}{*}{ Finland } & $6.213,31$ & 829,00 & $-0,75$ & 2,48 & $-42,02$ & $-4,11$ \\
\hline & (3461.98) & $16.045,05$ & $(0.23)$ & (17.19) & 68,57 & $(0.00)^{*}$ \\
\hline \multirow{2}{*}{ France } & $3.715,07$ & $1.785,71$ & $-0,43$ & 0,87 & $-36,30$ & $-4,26$ \\
\hline & (1253.98) & $6.565,97$ & $(0.33)$ & $(11.25)$ & 31,67 & $(0.00)^{*}$ \\
\hline \multirow{2}{*}{ Germany } & $4.845,57$ & $1.684,21$ & $-0,32$ & 1,92 & $-45,91$ & $-4,29$ \\
\hline & (1837.63) & $8.067,32$ & $(0.38)$ & (13.09) & 30,09 & $(0.00)^{*}$ \\
\hline \multirow{2}{*}{ Greece } & $2.309,14$ & 611,16 & $-0,21$ & 0,11 & $-47,12$ & $-3,83$ \\
\hline & $(1369.22)$ & $5.877,90$ & $(0.42)$ & (16.67) & 38,28 & $(0.00)^{*}$ \\
\hline \multirow{2}{*}{ Ireland } & $4.325,05$ & $1.275,28$ & $-0,16$ & 1,26 & $-45,51$ & $-3,52$ \\
\hline & $(2030.59)$ & $9.432,84$ & $(0.44)$ & (12.28) & 29,54 & $(0.00)^{*}$ \\
\hline \multirow{2}{*}{ Italy } & $1.198,24$ & 446,33 & $-0,35$ & 0,84 & $-29,68$ & $-4,78$ \\
\hline & $(460.97)$ & $2.058,23$ & $(0.36)$ & (12.00) & 39,59 & $(0.00)^{*}$ \\
\hline \multirow{2}{*}{ Japan } & $14.236,56$ & $8.017,75$ & $-0,96$ & $-0,61$ & $-25,58$ & $-5,73$ \\
\hline & (4118.01) & $22.379,02$ & $(0.17)$ & (11.05) & 22,51 & $(0.00)^{*}$ \\
\hline \multirow{2}{*}{ Netherlands } & 374,47 & 129,71 & $-0,28$ & 1,24 & $-38,19$ & $-4,34$ \\
\hline & (138.73) & 675,44 & $(0.39)$ & (12.47) & 33,51 & $(0.00)^{*}$ \\
\hline \multirow{2}{*}{ Portugal } & $7.602,52$ & $3.187,65$ & $-0,43$ & 0,75 & $-29,64$ & $-4,36$ \\
\hline & $(2685.05)$ & $13.384,90$ & $(0.33)$ & $(12.36)$ & 37,68 & $(0.00)^{*}$ \\
\hline \multirow{2}{*}{ Spain } & $7.191,65$ & 230,76 & $-0,62$ & 0,89 & $-38,89$ & $-4,59$ \\
\hline & $(3720.31)$ & $14.974,90$ & $(0.27)$ & (12.41) & 39,91 & $(0.00)^{*}$ \\
\hline \multirow{2}{*}{ Sweden } & 759,66 & 179,63 & $-0,82$ & 2,30 & $-34,81$ & $-3,88$ \\
\hline & $(315.65)$ & $1.368,99$ & $(0.21)$ & (12.31) & 37,23 & $(0.00)^{*}$ \\
\hline \multirow{2}{*}{ UK } & $2.467,17$ & $1.356,35$ & $-0,62$ & 1,07 & $-30,52$ & $-4,56$ \\
\hline & $(576.31)$ & $3.422,92$ & $(0.27)$ & (8.27) & 23,04 & $(0.00)^{*}$ \\
\hline \multirow{2}{*}{ US } & $1.064,36$ & 444,27 & $-0,30$ & 1,56 & $-25,56$ & $-4,06$ \\
\hline & $(320.00)$ & $1.569,19$ & $(0.38)$ & $(8.51)$ & 18,95 & $(0.00)^{*}$ \\
\hline
\end{tabular}

Note: $*$ indicates the rejection of the null of a unit root for the $95 \%$ significance level.

Table 3. Political instability variables.

Number of cabinet changes

Number of constitutional change

Number of legislative elections

Legislative Effectiveness

Regulatory Quality

Rule of Law

Government crises Purges

Annual number of anti-government demonstrations

\section{Strikes}

Guerrilla warfare

Riots

Revolutions

Coups D'état

Number of terrorist incidents per year Number of victims per incident CPI index of corruption Political rights index 


\author{
Voice and accountability \\ Political stability and absence of violence \\ Government effectiveness \\ Government (\% GDP) \\ Assassinations
}

\author{
Civil liberties \\ Control of corruption \\ Degree of openness \\ Polity scale
}

Source: WDI (World Development Indicators), CNTS (Cross National Time Series), Kaufmann et al. (2004), GTD (Global Terrorism Database), Transparency International, Freedom House International, Penn World Tables, Polity IV.

As mentioned in the methodology section, we estimated the correlation technique in order to find the indicator pairs that are related. The PI indicators that are correlated are excluded for further analysis. These are CORR for Australia, Belgium, Canada, Germany, Greece, Japan, Portugal, UK and the US; and ELECT and GOV for France and Ireland, respectively.

\section{Empirical results}

Table 4 and Table 5 presents the estimation results regarding the effects of PI indicators on the banking sector returns and the overall stock market returns, respectively. In both tables the first section presents the mean equation and the second section the variance equation of the GARCH-M model. This model allows for testing whether the uncertainty affects Banking returns / Stock market returns directly and whether the PI indicators affect Banking returns / Stock market returns separately.

According to the results of Table 4, the Bank returns $(G A R C H)$ variable is significant for Finland, Germany and Sweden showing that the uncertainty of Bank Returns does itself affects Bank Returns, while for the rest of the countries the variable is insignificant showing that the uncertainty of Bank Returns does not itself affect Bank Returns. This fact, if viewed in conjunction with the fact that some PI indicators are significant means that PI is sometimes more important explaining returns than the inherent uncertainty (volatility from the GARCH model) of the returns themselves. In the mean equation the PI indicators that are negative and significant are ELECT for Denmark (-27.57) and Germany (-23.68) and RIOT for France (23.32) and Greece (-141.66). Positive and significant are the GOV indicator for Belgium (35.38) and Portugal (14.64), ELECT for UK (10.86) and TERROR for Sweden (29.55). These results, showing that PI indicators are affecting Bank Returns not only negatively but sometimes with a positive impact indicate that the issue of PI is rather complex and does not provide all necessary information when viewed in aggregation. Therefore, the fact that all PI is not 'bad' for returns, requires from financial analysts to explore further what particular types/characteristics of PI might affect one country compared to another. Furthermore, we tested for possible autocorrelation of higher order by using the Ljung-box test and for possible ARCH effects. The results of Table 2 are very satisfactory and show that there are no signs of autocorrelation and ARCH effects in the data.

In the variance equation the PI indicators that are negative and significant are CORR for Ireland (-325.85), ELECT for Greece (-504.26), Japan (-87.04) and Portugal (-616.85), GOV for Japan (-57.29) and Portugal (-82.30), RIOT for the US (-168.47) and TERROR for Japan (143.02), affecting so the variance of Bank Returns. Thus, we conclude first, that the PI indicators have a direct effect on Bank Returns for Belgium, Denmark, Finland, France, Germany, Sweden and the UK while they do not have an indirect effect on the variance of Bank Returns; second, that the PI indicators have not a direct effect on Bank Returns for Ireland, Japan and the US while they do have an indirect effect on the variance of Bank Returns; and third, the PI indicators have both an direct effect on Bank Returns and indirect effect on the variance of Bank Returns for Greece and Portugal. Thus, again these results suggest that PI is 
rather complex and cannot be viewed in isolation of the particularities of every country case.

Similar to Table 4, Table 5 shows that the Stock Market Returns (GARCH) variable is significant for Austria, Japan and Portugal showing that the uncertainty of Stock Market Returns does itself affect Stock Market Returns, while for the rest of the countries the variable is insignificant showing that the uncertainty of Stock Market Returns does not itself affect Stock Market Returns. In the mean equation the PI indicators that are negative and significant are ELECT for Denmark (-28.02) and the US (-22.52), GOV for Sweden (-5.69) and RIOT for Greece (-65.06) and Italy (-121.71). Positive and significant are the GOV indicator for Belgium (16.79) and Japan (9.80) and TERROR for Greece (57.88). These results are showing that the PI indicators can affect Stock Market Returns both negatively and/or positively.

In the variance equation the PI indicators that are negative and significant are ELECT for Belgium (-53.52), GOV for Belgium (-60.66) and the UK (-46.32), RIOT for the France (121.22) and Germany (-220.38) and TERROR for Ireland (-86.75) and Portugal (-832.31) affecting so the variance of Stock Market Returns. Furthermore, two indicators, the CORR for France (90.19) and the GOV for Germany (15.95) are positive and significant affecting also the variance of Stock Market Returns. Thus, we conclude first, that the PI indicators have a direct effect on Stock Market Returns for Austria, Denmark, Greece, Italy, Japan, Sweden and the US while they do not have an indirect effect on the variance of Stock Market Returns; second, that the PI indicators have not a direct effect on Stock Market Returns for France, Germany, and Ireland while they do have an indirect effect on the variance of Stock Market Returns; and third, the PI indicators have both an direct effect on Stock Market Returns and indirect effect on the variance of Stock Market Returns for Belgium, Portugal and the UK. Here, again the results of the Ljung-box test of autocorrelation and the ARCH effects test are satisfactory and show that there are no signs of autocorrelation and ARCH effects.

Furthermore, from table 4 and 5 it is possible to compare the effects that each indicator has on each country and among countries. For example, in the mean equation of table 2 the RIOT indicator shows to have a negative impact in France while the other indicators did not have neither a positive or negative impact. If the RIOT indicator is compared among countries then only Greece shows to be negatively affected while other countries are not. ${ }^{1}$

\section{Conclusions}

The present paper empirically examines the relationship between PI, banking stock returns and the overall stock market returns during the period of 1993-2013 using time series data at country level. We constructed five PI indicators from 27 different PI variables that are mentioned in the empirical literature. From the overall results of our study, although we provide strong evidence for the existence of a direct negative relationship between the PI indicators and Bank Returns / Stock Market Returns and an indirect negative relationship between the PI indicators and the variance of the Banking returns and the Overall Stock Market returns (as most other studies do), there are a few additional outcomes that need to be carefully considered. Particularly, we find that not all PI indicators have negative effects and there are some with non-significant and also sometimes positive results. Thus, not all PI is bad for market and banking returns. Even more, various PI indicators are affecting differently some countries compared to others, while the effect of PI indicators is not always the same for stock market and banking returns. These findings show clearly that the issue of PI is rather complex and

\footnotetext{
${ }^{1}$ Further to our initial analysis that includes all political instability indicators, the models reported in Tables 4 and 5 were re-estimated with the significant indicators only. The results were not different from the ones reported and therefore, for reasons of economy of space are not reported here. Tables and results are available from authors upon request.
} 
when viewed in aggregation does not provide clear results for particular country cases. We believe that studying PI in a country context allowing for idiosyncrasies for every particular country are of major importance in understanding the role of PI on stock market stability and are of great significance to investors and market regulators. Obviously, the topic is open for further research in order to understand the deeper effects of PI on returns and examine in particular what are those idiosyncrasies that differentiate the effects for different country cases.

\section{References}

Addoum, J.M. and Kumar, A. (2016) Political Sentiment and Predictable Returns, The Review of Financial Studies, forthcoming.

Bussiere, M. and Mulder, C. (1999) Political instability and economic vulnerability, IMF Working Papers, No. 9946.

Chesney, M., Reshetarb, G., Karamana, M. (2011) The impact of terrorism on financial markets: an empirical study, Journal of Banking and Finance, 35(2), 253-267.

Diamonte, R.L., Liew, J.M., Stevens, R.L. (1996) Political risk in emerging and developed markets, Financial Analysts Journal, 52(3), 71-76.

Enders, W. (1995) Applied econometric time series, New York: Wiley.

Engle, R.F., Lilien, D.M., and Robins, R.P. (1987) Estimating Time Varying Risk Premia in the Term Structure: The ARCH -M Model, Econometrica, March, 55, 391-407.

Fabriger, L.R. and Wegener, D.T. (2011) Exploratory Factor Analysis Understanding Statistics, Oxford University Press: New York.

Gemmill, G., (1992) Political risk and market efficiency: tests based in British stock and options markets in the 1987 election, Journal of Banking and Finance, 16, 211-231.

Huang, T., Wu, F., Yu, J. and Zhang, B. (2015), International political risk and government bond pricing, Journal of Banking \& Finance, 55, 393-405.

Jackson, A.O. (2008) The impact of the 9/11 terrorist attacks on the US economy, Workings Papers of the Florida Memorial University.

Jong-a-Pin, R. (2009) On the measurement of political instability and its impact on economic growth, European Journal of Political Economy, 25, 15-29.

Lehkonen, H. and Heimonen, K. (2015) Democracy, political risks and stock market performance, Journal of International Money and Finance, 59, 77-99.

Li, J., Born, J.A. (2006) Presidential election uncertainty and common stock returns in the United States, Journal of Financial Research, 29, 609-622.

Smales, A.L. (2014) Political uncertainty and financial market uncertainty in an Australian context, Journal of International Financial Markets, Institutions and Money 32, 415-435. 
Table 4. GARCH-M $(1,1)$ estimates of Bank Returns with political instability indicators in mean and variance, dependent variable Bank Returns.

\begin{tabular}{|c|c|c|c|c|c|c|c|c|c|c|c|c|c|c|c|c|c|c|}
\hline Parameter & Australia & Austria & Belgium & Canada & Denmark & Finland & France & Germany & Greece & Ireland & Italy & Japan & Netherlands & Portugal & Spain & Sweden & UK & us \\
\hline \multicolumn{19}{|l|}{ Mean equation } \\
\hline constant & 0.239 & -0.812 & $-23.284 *$ & -1.188 & 7.133 & -18.821 & $12.245+$ & $19.329^{*}$ & -5.841 & 4.198 & 11.231 & -1.845 & -8.781 & -15.636 & -1.653 & 8.459 & -1.587 & \\
\hline \multirow{3}{*}{ Bank Returns } & $(0.052)$ & $(-0.128)$ & $(-2.159)$ & $(-0.166)$ & $(1.026)$ & $(-1.211)$ & -1.945 & $(2.262)$ & $(-0.194)$ & $(0.228)$ & $(0.499)$ & $(-0.224)$ & $(-1.006)$ & $(-0.767)$ & $(-0.159)$ & $(0.456)$ & $(-0.247)$ & $(-0.488)$ \\
\hline & 0.137 & $0.162^{*}$ & $-0.226+$ & -0.068 & -0.143 & -0.067 & 0.023 & $-0.196+$ & 0.065 & -0.214 & -0.027 & 0.132 & 0.252 & -0.030 & -0.114 & -0.116 & 0.109 & -0.154 \\
\hline & $(0.875)$ & $(2.065)$ & $(-1.731)$ & $(-0.404)$ & $(-0.578)$ & $(-0.527)$ & $(0.218)$ & $(-1.905)$ & $(0.536)$ & $(-0.686)$ & $(-0.186)$ & (1.143) & $(1.604)$ & $(-0.288)$ & $(-0.669)$ & $(-0.585)$ & $(0.624)$ & $(-0.961)$ \\
\hline \multirow[t]{2}{*}{ Bank Returns (GARCH) } & -0.006 & 0,01 & 0.005 & 0.025 & 0.002 & $0.084+$ & 0.008 & $-0.071 * *$ & -0.018 & -0.000 & 0.004 & -0.039 & 0.004 & -0.001 & 0.017 & $0.061^{* *}$ & -0.022 & 0.010 \\
\hline & $(-0.114)$ & $(0.594)$ & $(1.284)$ & $(0.764)$ & $(0.507)$ & $(1.966)$ & $(0.724)$ & $(-3.095)$ & $(-0.431)$ & $(-0.163)$ & $(1.094)$ & $(-1.589)$ & $(0.334)$ & $(-0.224)$ & $(1.029)$ & $(2.904)$ & $(-1.428)$ & $(0.438)$ \\
\hline \multirow[t]{2}{*}{ CORR } & & 3.361 & & & -0.061 & 4.458 & -8.782 & & & -5.019 & 1.278 & & -1.491 & & -33.307 & -18.345 & & \\
\hline & & $(0.542)$ & & & $(-0.008)$ & $(0.509)$ & $(-1.090)$ & & & $(-0.503)$ & $(0.118)$ & & $(0.206)$ & & $(-0.507)$ & $(-0.894)$ & & \\
\hline \multirow[t]{2}{*}{ ELECT } & -7.948 & $\begin{array}{l}-0.794 \\
-0.073\end{array}$ & 2.237 & -0.350 & $-27.569^{*}$ & -2.149 & & $-23.682 * *$ & 3.076 & & 2.979 & 3.806 & -0.703 & 12.714 & 1.105 & -5.843 & 10.859 ** & -6.206 \\
\hline & $(-1.399)$ & $(-0.073)$ & $(0.239)$ & $(-0.039)$ & $(-2.792)$ & $(-0.346)$ & & $(-24.164)$ & $(0.164)$ & & $(0.151)$ & $(0.342)$ & $(-0.069)$ & $(0.557)$ & $(0.1)$ & $(-0.788)$ & (18.552) & $(-0.319)$ \\
\hline \multirow{2}{*}{ GOV } & 0.093 & -3.271 & $35.383 * *$ & 5.468 & -1.476 & 5.919 & & 4.486 & 3.183 & & 10.599 & 6.407 & 20.106 & $14.642^{*}$ & & -10.269 & 5.7 & 3.956 \\
\hline & $(0.019)$ & $(-0.466)$ & $(14.376)$ & $(1.041)$ & $(-0.192)$ & $(0.522)$ & & $(0.789)$ & $(0.022)$ & & (1.577) & $(1.300)$ & $(1.4$ & (2.249) & $(0.4$ & $(-1.472)$ & $(1.004)$ & $(0.609)$ \\
\hline \multirow{2}{*}{ RIOT } & 2.344 & 7.387 & 7.877 & 10.078 & 2.767 & & $-23.321+$ & -83.322 & $-141.660 *$ & 5.915 & $-94.7 \quad$ & -22.063 & -54.698 & -406.369 & -21.444 & 16.398 & -1.289 & 12.473 \\
\hline & $(0.370)$ & $(1.142)$ & $(0.839)$ & $(0.496)$ & $(0.443)$ & & $(-1.856)$ & $(-1.305)$ & $(-2.917)$ & $(0.248)$ & $(-1.178)$ & $(-0.749)$ & $(-1.412)$ & $(-1.307)$ & $(-0.451)$ & $(1.522)$ & $(-0.059)$ & $(1.049)$ \\
\hline \multirow{2}{*}{ TERROR } & 8.448 & & -1.805 & -4.801 & 19.136 & -10.822 & 17.545 & & 53.318 & 12.178 & -38.455 & 15.001 & 8.524 & -63.676 & 8.778 & $29.551^{*}$ & -4.688 & -1.924 \\
\hline & $(0.909)$ & & $(-0.040)$ & $(-0.353)$ & (1.445) & $(-0.959)$ & $(0.625)$ & & $(1.535)$ & $(0.223)$ & $(-0.363)$ & $(2.271$ & (1.064) & $(-1.489)$ & $(0.696)$ & $(2.242)$ & $(-0.329)$ & $(-0.245$ \\
\hline \multicolumn{19}{|l|}{ Variance equation } \\
\hline \multirow{2}{*}{ constant } & 29.147 & $101.649 \%$ & $341.730+$ & 81.117 & 170,245 & $175.799 \%$ & 85.051 & 274.771 & $398.435 \%$ & 828.568 & 167.851 & $143.037^{* *}$ & 99.145 & $645.878 *$ & 169.319 & 106.889 & 170.362 & 66.739 \\
\hline & $(0.480)$ & $(2.287)$ & & & & $(2.045)$ & $(0.773)$ & (1.575) & $(3.750)$ & & & & $(0.761)$ & $(5.965)$ & & & $(1.029)$ & $(1.308)$ \\
\hline \multirow{2}{*}{$\mathrm{ARCH}(1)$} & 0.080 & 0,073 & $0.882 *$ & -0.019 & 0,422 & $-0.087+$ & $1.341^{*} *$ & $-0.148+$ & $-0.101+$ & 0.838 & 0.022 & $-0.221 * \%$ & 0.751 & $-0.055^{*}$ & 0.099 & -0.042 & 0.605 & 0.107 \\
\hline & $(0.491)$ & (1.032) & (2.139) & $(-0.154)$ & $(0.988)$ & $(-1.938)$ & $(-2.725)$ & $(-1.822)$ & $(-1.849)$ & (1.164) & $(0.334)$ & $(-3.155)$ & & $(-2.207)$ & $(0.560)$ & & & $(1.183)$ \\
\hline \multirow[t]{2}{*}{ GARCH $(1)$} & 0.566 & $0.703 * *$ & 0.069 & 0.457 & 0,102 & $0.743 * *$ & 0.180 & 0.406 & $0.556 *$ & 0.358 & 0.532 & $0.962 * *$ & -0.012 & $0.816 * *$ & $0.555+$ & -0.002 & -0.200 & $0.811^{* * *}$ \\
\hline & $(0.479)$ & $(7.929)$ & $(0.696)$ & $(0.843)$ & $(0.401)$ & $(4.565)$ & $(1.132)$ & $(0.837)$ & (2.401) & $(1.303)$ & $(1.358)$ & (12.474) & $(-1.019)$ & $(8.736)$ & $(1.675)$ & $(-0.021)$ & $(-0.777)$ & (6.186) \\
\hline \multirow[t]{2}{*}{ CORR } & & 40.584 & & & -31.803 & -80.735 & -6.126 & & & $-325.857+$ & -31.167 & & 184.883 & & -746.573 & 113.452 & & \\
\hline & & $(1.009)$ & & & $(-0.179)$ & $(-1.322)$ & $(-0.041)$ & & & $(-1.908)$ & $(-0.459)$ & & (1.164) & & $(-0.904)$ & $(0.257)$ & & \\
\hline \multirow[t]{2}{*}{ ELECT } & -22.557 & -164.524 & -181.902 & 0.005 & -280.839 & -41.986 & & -1.349 & $-504.262 * *$ & & 1.588 & $-87.049 * *$ & 24.856 & $-616.858 * *$ & -44.678 & 26.637 & -23.234 & 57.156 \\
\hline & $(-0.481)$ & $(-1.528)$ & $(-1.265)$ & $(0.001)$ & $(-1.296)$ & $(-1.103)$ & & $(-0.005)$ & $(-2.869)$ & & $(0.010)$ & & $(0.129)$ & & & $(0.213)$ & & $(0.672)$ \\
\hline \multirow[t]{2}{*}{ GOV } & 16.070 & -56.818 & -307.993 & -52.218 & 106.791 & -91.019 & & & -245.187 & & -0.959 & $-57.297 * *$ & -119.999 & $-82.305^{* * *}$ & $16.150)$ & -40.535 & -102.505 & -69.111 \\
\hline & $(0.237)$ & $(-0.979)$ & $(-1.367)$ & $(-1.313)$ & (1.159) & $(-1.057)$ & & -181.002 & $(-1.26$ & & $(-0.016)$ & $(-10.899)$ & $(-0.694)$ & & $(0.169)$ & $(-0.297)$ & $(-0.619)$ & $(-1.486)$ \\
\hline \multirow{2}{*}{ RIOT } & 12.012 & -53.211 & -90.742 & -0.2 & 56.78 & & -157.746 & $(-1.604)$ & 2895 . & -824.900 & -8. & -111 & & & & -43. & -278.265 & $-168.478^{* *}$ \\
\hline & $(-0.183)$ & $(-0.986)$ & $(-0.629)$ & $(-0.002)$ & $(0.369)$ & & $(-0.505)$ & -32.151 & $(1.192)$ & $(-1.321)$ & $(-0.009)$ & $(-1.114)$ & $(-0.075)$ & & & $(-0.221)$ & $(-0.657)$ & $(-3.856)$ \\
\hline \multirow[t]{2}{*}{ TERROR } & -17.930 & & 24.170 & -0.136 & -14.013 & -40.380 & 107.393 & $(-0.034)$ & -7.674 & -118.419 & -1607.973 & $-143.029 * *$ & -94.649 & 25.170 & -28.155 & -229.109 & 181.935 & 11.473 \\
\hline & $(-0.270)$ & & $(0.078)$ & $(-0.001)$ & $(-0.074)$ & $(-1.174)$ & $(0.157)$ & & $(-0.027)$ & $(-0.126)$ & $(-1.163)$ & $(-21.987)$ & $(-0.497)$ & $(0.294)$ & $(-0.266)$ & $(-1.666)$ & $(0.546)$ & $(0.312)$ \\
\hline \multicolumn{19}{|l|}{$\begin{array}{l}\text { Diagnostics } \\
\end{array}$} \\
\hline & 0.0 & 0,04 & -0.00 & -0.034 & 0,03 & 0,109 & -0.056 & 0.1 & 0.158 & -0.1 & 0,12 & 0,022 & 0,1 & 0,1 & 0,0 & 0,2 & 0,0 & 0,025 \\
\hline Adj R-squared & & & & & & & & & & & & & & & & & & $-0,0$ \\
\hline DW stat & & 1,821 & 1.3 & & & & & & & & & & & & & & & 50 \\
\hline Ljung-Box (4) & 0,417 & 1,184 & 2,930 & 1.278 & & 1,4 & 0,458 & 2.19 & 2,061 & 9,41 & & 5,3 & 0,7 & 1,5 & & 0,8 & 5,312 & 3,398 \\
\hline & $(0.981)$ & $(0.881)$ & $(0.570)$ & $(0.120)$ & $(0.816)$ & $(0.84)$ & $(0.977)$ & $(0.70$ & $(0.725)$ & $(0.152)$ & $(0.4$ & $(0.2$ & $(0.9$ & $(0.8$ & $(0.8$ & $(0.92$ & $(0.257)$ & $(0.493)$ \\
\hline $\operatorname{Arch}(4)$ & $-0,663$ & 0,256 & $-0,529$ & $-0,364$ & $-0,269$ & $-0,837$ & 0,152 & $-0,521$ & 0,753 & $-0,001$ & $-1,241$ & $-1,489$ & $-1,395$ & $-0,100$ & $-0,138$ & $-1,424$ & 0,062 & 0,531 \\
\hline & $(0.509)$ & $(0.799)$ & $(0.598)$ & $(0.717)$ & $(0.788)$ & $(0.406)$ & $(0.879)$ & $(0.604)$ & $(0.454)$ & $(0.999)$ & $(0.218)$ & $(0.141)$ & $(0.168)$ & $(0.919)$ & $(0.891)$ & $(0.159)$ & $(0.951)$ & $(0.597)$ \\
\hline
\end{tabular}

Notes: Values of t-statistics are in parentheses. Bold figures indicate statistical significant coefficients, $* *$ denotes statistical significance at the $1 \%$ level $(\mathrm{p}<0.01), *$ denotes statistical significance at the $5 \%$ level $(\mathrm{p}<0.05),+$ denotes statistical significance at the $10 \%$ level $(\mathrm{p}<0.1)$ 
Table 5. GARCH-M $(1,1)$ estimates of Stock Market Returns with political instability indicators in mean and variance, dependent variable Stock Market Returns.

\begin{tabular}{|c|c|c|c|c|c|c|c|c|c|c|c|c|c|c|c|c|c|c|}
\hline Parameter & Australia & Austria & Belgium & Canada & Denmark & Finland & France & Germany & Greece & Ireland & Italy & Japan & Netherlands & Portugal & Spain & Sweden & UK & US \\
\hline \multicolumn{19}{|l|}{ Mean equation } \\
\hline constant & -0.383 & $18.53^{* * *}$ & -4.961 & 6.950 & $15.349 * *$ & 14.073 & 1.155 & 4.888 & $-31.792+$ & -0.668 & $25.255+$ & 6.289 & 0.614 & 10.492 & 1.913 & $23.202+$ & 1.402 & 7.267 \\
\hline \multirow{3}{*}{ Stock Market Returns } & $(-0.118)$ & $(6.204)$ & $(-1.068)$ & (1.449) & $(2.720)$ & $(0.855)$ & $(0.219)$ & $(0.681)$ & $(-1.689)$ & $(-0.103)$ & $(1.902)$ & $(1.010)$ & $(0.051)$ & $(0.299)$ & $(0.275)$ & (1.731) & $(0.368)$ & $(1.627)$ \\
\hline & 0.026 & 0.048 & 0.040 & 0.223 & 0.041 & 0.012 & 0.189 & -0.078 & $0.225 * \%$ & 0.004 & 0.020 & 0.117 & -0.144 & -0.142 & -0.066 & 0.002 & 0.092 & -0.015 \\
\hline & $(0.133)$ & $(0.399)$ & $(0.282)$ & $(1.605)$ & $(0.319)$ & $(0.074)$ & $(1.229)$ & $(-0.622)$ & $(2.654)$ & $(0.027)$ & $(0.126)$ & $(0.957)$ & $(-0.492)$ & $(-0.837)$ & $(-0.430)$ & $(0.011)$ & $(0.789)$ & $(-0.086)$ \\
\hline \multirow[t]{2}{*}{ Stock Market Returns (GARCH) } & -0.009 & $-0.143 * *$ & 0.006 & -0.062 & -0.003 & -0.002 & 0.007 & -0.008 & 0.031 & -0.005 & 0.035 & $-0.113^{*}$ & 0.006 & $-0.206+$ & 0.009 & 0.0145 & 0.007 & -0.002 \\
\hline & $(-0.206)$ & $(-4.934)$ & $(0.336)$ & $(-1.527)$ & $(-0.348)$ & $(-0.115)$ & $(0.490)$ & $(-0.275)$ & $(1.038)$ & $(-0.340)$ & $(0.925)$ & $(-2.002)$ & $(0.340)$ & $(-1.779)$ & $(0.845)$ & $(0.454)$ & $(0.754)$ & $(-0.060)$ \\
\hline \multirow[t]{2}{*}{ CORR } & & $15.795^{*}$ & & & -6.962 & -8.785 & -1.997 & & & 2.661 & -3.519 & & -14.662 & & -58.281 & -28.855 & & \\
\hline & & $(2.047)$ & & & $(-1.027)$ & $(-0.576)$ & $(-0.297)$ & & & $(0.507)$ & $(-0.537)$ & & $(-0.912)$ & & $(-0.984)$ & $(-1.539)$ & & \\
\hline \multirow[t]{2}{*}{ ELECT } & -7.744 & -7.158 & 9.953 & 3.627 & $-28.021 * *$ & 5.994 & & 0.899 & 10.151 & & -9.962 & 5.175 & -9.632 & 22.375 & 2.719 & -3.307 & $8.153^{*}$ & $-22.523 * *$ \\
\hline & $(-1.524)$ & $(-1.443)$ & (1.411) & $(0.795)$ & $(-4.607)$ & $(0.598)$ & & $(0.054)$ & $(0.804)$ & & $(-0.839)$ & $(0.547)$ & $(-0.876)$ & $(0.715)$ & $(0.414)$ & $(-0.463)$ & (2.367) & $(-3.747)$ \\
\hline \multirow{2}{*}{ GOV } & 5.319 & -7.723 & 16.791 & 0.553 & -3.651 & -9.514 & & -0.502 & 25.262 & & 1.475 & $9.806 *$ & 17.166 & 8.662 & 8.677 & $-5.690^{*}$ & 0.049 & -0.205 \\
\hline & $(1.482)$ & $(-0.898)$ & (3.479) & $(0.187)$ & $(-0.686)$ & $(-0.467)$ & & $(-0.095)$ & $(0.294)$ & & $(0.380)$ & (2.139) & (1.448) & (1.254) & $(1.256)$ & $(-2.311)$ & $(0.013)$ & $(-0.041)$ \\
\hline \multirow{4}{*}{ TERROR } & -3.957 & -1.346 & 6.055 & -16.575 & 5.650 & & 4.254 & -22.951 & $-65.067+$ & 5.228 & $-121.712^{*}$ & -12.884 & -87.888 & -210.876 & -13.513 & 11.684 & -13.553 & -0.638 \\
\hline & $(-0.487)$ & $(-0.256)$ & $(0.689)$ & $(-1.266)$ & (1.137) & & $(0.376)$ & $(-0.666)$ & $(-1.824)$ & $(0.447)$ & $(-2.146)$ & $(-0.475)$ & $(-1.194)$ & $(-0.990)$ & $(-0.563)$ & $(0.583)$ & $(-0.974)$ & $(-0.103)$ \\
\hline & 6.259 & & -31.491 & -0.137 & 3.956 & -21.683 & 5.578 & & $57.886 *$ & 4.320 & -82.918 & 2.949 & 8.167 & -34.324 & 8.768 & 15.274 & -1.544 & -6.692 \\
\hline \multirow{2}{*}{\multicolumn{19}{|c|}{ Variance equation }} \\
\hline & & & & & & & & & & & & & & & & & & \\
\hline \multirow[t]{2}{*}{ constant } & 11.259 & 68.302 & 21.354 & 55.538 & 32.659 & 190.596 & 13.162 & 5.548 & 231.302 & 59.374 & 131.236 & 91.79 & 128.996 & 128.369 & 63.019 & 133.464 & 29.596 & 21.275 \\
\hline & & & & $(0.863)$ & & & $(0.488)$ & $(0.555)$ & & & & & & & & & & $(0.996)$ \\
\hline \multirow[t]{2}{*}{$\mathrm{ARCH}(1)$} & $0.380^{* * *}$ & $\begin{array}{r}-0.103 \\
-1534\end{array}$ & 0.201 & $\begin{array}{r}-0.073 \\
-0.331\end{array}$ & $\begin{array}{l}-0.106 \\
-0.091\end{array}$ & $\begin{array}{l}-0.106 \\
-1.364\end{array}$ & $\begin{array}{l}0.161 * * \\
0\end{array}$ & $-0.123 * * *$ & $-0.188 * * *$ & $0.299 *$ & $\begin{array}{c}0.243 \\
0863\end{array}$ & $\begin{array}{l}-0.194 \\
-1.3089\end{array}$ & 0.13 & $-0.161 * *$ & $\begin{array}{r}0.060 \\
0.573\end{array}$ & 0.128 & $0.685 * *$ & $\begin{array}{c}0.236 \\
01569\end{array}$ \\
\hline & & $\begin{array}{l}(-1.534) \\
0568\end{array}$ & $\begin{array}{l}(1.034) \\
0.590 * *\end{array}$ & $(-0.331)$ & $\begin{array}{l}(-0.991) \\
0534\end{array}$ & & (159.319) & $(-4.839)$ & $(-3.057)$ & $(2.117)$ & $(0.863)$ & $(-1.308)$ & $(0.347)$ & $(-3.307)$ & $(0.573)$ & $(0.629)$ & $(2.608)$ & (1.569) \\
\hline GARCH $(1)$ & $\begin{array}{l}\mathbf{0 . 4 2 6 +} \\
(1.684)\end{array}$ & $\begin{array}{l}0.568 \\
(0.977)\end{array}$ & $\begin{array}{l}0.590^{0 * *} \\
(2.943)\end{array}$ & $\begin{array}{c}0.434 \\
(0.609)\end{array}$ & $\begin{array}{r}0.534 \\
(1.357)\end{array}$ & $\begin{array}{l}0.567 \\
(0.833)\end{array}$ & $\begin{array}{l}\mathbf{0 . 6 2 0} \mathbf{O}^{* * *} \\
(4.982)\end{array}$ & $\begin{array}{c}\mathbf{1 . 0 8 7 * *}_{(2122.842)} \\
\text { (1) }\end{array}$ & $\begin{array}{l}0.322 \\
0.586\end{array}$ & $\begin{array}{l}0.555 * * \\
(2.682)\end{array}$ & $\begin{array}{l}0.002 \\
(0.004)\end{array}$ & 0.227 & $\begin{array}{r}0.590 \\
(1.185)\end{array}$ & $\begin{array}{r}0.404 \\
0.444\end{array}$ & $\begin{array}{r}0.520 \\
0(300\end{array}$ & $\begin{array}{r}0.403 \\
0.795\end{array}$ & $0.374 *$ & $0.745 * *$ \\
\hline \multirow{2}{*}{ CORR } & & 26.041 & & & -36.139 & -3.008 & $90.195+$ & & & -19.925 & -121.393 & & -0.977 & & -1.994 & 4.143 & & \\
\hline & & $(0.454)$ & & & $(-0.863)$ & $(-0.022)$ & (1.780) & & & $(-0.530)$ & $(-1.379)$ & $(0.204)$ & $(-0.006)$ & & $\begin{array}{l}-1.974 \\
(-0.005)\end{array}$ & $\begin{array}{l}(0.019) \\
(0.149\end{array}$ & & \\
\hline \multirow[t]{2}{*}{ ELECT } & 37.155 & -50.219 & $-53.529+$ & -62.089 & 2.562 & -2.889 & & -8.711 & -132.542 & & -114.569 & 32.028 & -0.004 & -6.559 & -16.052 & 38.712 & 24.788 & -26.898 \\
\hline & $(0.988)$ & $(-0.827)$ & $(-1.845)$ & $(-0.858)$ & $(0.061)$ & $(-0.021)$ & & $(-0.133)$ & $(-0.655)$ & & $(-0.583)$ & $(0.216)$ & & $(-0.030)$ & $(-0.240)$ & $(0.504)$ & $(1.335)$ & $(-1.231)$ \\
\hline \multirow[t]{2}{*}{ GOV } & -5.230 & 33.406 & $-60.662+$ & 14.466 & 146.509 & -5.555 & & $15.950^{*}$ & 35.716 & & 17.262 & -6.277 & -0.797 & 12.039 & 11.975 & -138.028 & $-46.329+$ & -10.387 \\
\hline & $(-0.262)$ & $(0.307)$ & $(-1.696)$ & $(0.565)$ & (1.209) & $(-0.025)$ & & $(2.504)$ & $(0.023)$ & & $(0.306)$ & $(-0.121)$ & $(-0.0$ & $(0.315)$ & $(0.189)$ & $(-1.090)$ & $(-1.816)$ & $(-0.436)$ \\
\hline \multirow[t]{2}{*}{ RIOT } & 27.141 & -44.671 & 34.908 & 8.693 & 10.426 & & $-121.229 \%$ & $-220.385 * *$ & 78.831 & -43.625 & 515.438 & -0.971 & -66.310 & -3.956 & -51.383 & $\begin{array}{r}-39.712 \\
\end{array}$ & 52.792 & -51.679 \\
\hline & $(0.623)$ & $(-0.505)$ & (0.498) & $(0.587)$ & $(0.318)$ & & $(-2.003)$ & $(-4.550)$ & $(0.227)$ & $(-0.658)$ & $(0.614)$ & $(-0.003)$ & $(-0.071)$ & $(-0.002)$ & $(-0.201)$ & $(-0.441)$ & $(0.560)$ & $(-1.636)$ \\
\hline \multirow[t]{2}{*}{ TERROR } & -25.547 & & 175.859 & -19.653 & 3.692 & -43.450 & -109.979 & & 2.969 & -86.75 & 97.8 & -6.435 & -182.941 & -832.3 & -71.080 & 1.504 & 23.601 & -9.793 \\
\hline & $(-0.575)$ & & $(1.215)$ & $(-0.227)$ & $(0.092)$ & $(-0.136)$ & $(-0.869)$ & & $(0.008)$ & $(-2.049)$ & $(0.229)$ & $(-0.526)$ & $(-1.134)$ & $(-2.687)$ & $(-1.190)$ & $(0.012)$ & $(0.889)$ & $(-0.169)$ \\
\hline \multicolumn{19}{|l|}{ Diagnostics } \\
\hline \multirow{3}{*}{$\begin{array}{l}\text { R-squared } \\
\text { Adj R-squared } \\
\text { DW stat }\end{array}$} & 0.0 & 0.144 & -0.00 & & 0.137 & 0.0 & -0.026 & -0.023 & 0.12 & 0.005 & 0.0 & 0.1 & 0.1 & & 0.0. & 0.10 & -0.039 & 0.011 \\
\hline & -0.0 & 0.073 & -0.0 & -0.0 & & -0.027 & -0.0 & -0.05 & 0.0 & -0.062 & -0.0 & 0.0 & 0.0 & -0.0 & -0.0 & 0.0 & -0.12 & -0.071 \\
\hline & 1.631 & 1.669 & 1.859 & 2.221 & 1.9 & 2.154 & 2.17 & 1.845 & 2.165 & 1.791 & 1.81 & 1.9 & 1.8 & 1.6 & 2.086 & 1.984 & 1.897 & 1.847 \\
\hline \multirow{2}{*}{ Ljung-Box (4) } & 0.855 & 1.645 & 3.3 & 4.244 & 3.341 & 1.768 & 26.786 & 1.127 & 1.738 & 2.45 & 0.6 & 8.269 & 1.5 & 3.4 & 1.579 & 1.930 & 1.804 & 1.131 \\
\hline & $(0.931)$ & $(0.801)$ & $(0.497)$ & $(0.374)$ & $(0.50$ & $(0.77$ & $(0.14$ & $(0.890)$ & $(0.784)$ & $(0.652)$ & $(0.951)$ & $(0.1$ & $(0.809)$ & $(0.48$ & $(0.813)$ & $(0.74$ & $(0.772)$ & $(0.889)$ \\
\hline & -1.407 & 0.488 & -1.262 & -0.735 & -1.161 & 0.607 & -1.161 & -0.751 & 1.369 & -0.554 & -1.003 & -1.495 & 0.100 & 0.019 & -1.095 & 0.015 & -0.218 & -0.905 \\
\hline $\operatorname{Arch}(4)$ & $(0.164)$ & $(0.627)$ & $(0.211)$ & $(0.466)$ & $(0.249)$ & $(0.546)$ & $(0.247)$ & $(0.455)$ & $(0.175)$ & $(0.581)$ & $(0.319)$ & $(0.139)$ & $(0.920)$ & $(0.984)$ & $(0.277)$ & $(0.988)$ & $(0.828)$ & $(0.368)$ \\
\hline
\end{tabular}

Notes: Values of t-statistics are in parentheses. Bold figures indicate statistical significant coefficients, ** denotes statistical significance at the $1 \%$ level (p<0.01), * denotes statistical significance at the 5\% level $(\mathrm{p}<0.05),+$ denotes statistical significance at the $10 \%$ level $(\mathrm{p}<0.1)$ 


\section{Appendix A.}

\section{Components of political instability indicators.}

Table A1. Components of political instability indicators for each country.

\begin{tabular}{|c|c|c|c|c|c|}
\hline COUNTRY & GOV & CORR & TERROR & ELECT & RIOT \\
\hline Australia & $\begin{array}{c}\text { Regulatory Quality } \\
\text { Rule of Law } \\
\text { Government effectiveness }\end{array}$ & $\begin{array}{l}\text { Control of corruption } \\
\text { CPI index of corruption }\end{array}$ & $\begin{array}{c}\text { Number of victims per incident } \\
\text { Number of terrorist incidents per year }\end{array}$ & $\begin{array}{c}\text { Number of cabinet changes } \\
\text { Number of legislative elections } \\
\text { Government crises }\end{array}$ & $\begin{array}{c}\text { Strikes } \\
\text { Riots } \\
\text { Assassinations }\end{array}$ \\
\hline Austria & $\begin{array}{l}\text { Government crises } \\
\text { Government effectiveness }\end{array}$ & $\begin{array}{c}\text { Rule of Law } \\
\text { CPI index of corruption } \\
\text { Voice and accountability }\end{array}$ & & $\begin{array}{l}\text { Number of cabinet changes } \\
\text { Number of legislative elections }\end{array}$ & $\begin{array}{c}\text { Riots } \\
\text { Strikes } \\
\text { Annual number of anti-government } \\
\text { demostrations }\end{array}$ \\
\hline Belgium & $\begin{array}{l}\text { Government effectiveness } \\
\text { Voice and accountability } \\
\text { Control of corruption }\end{array}$ & $\begin{array}{c}\text { Civil liberties } \\
\text { CPI index of corruption }\end{array}$ & $\begin{array}{l}\text { Number of terrorist incidents per year } \\
\text { Number of victims per incident }\end{array}$ & $\begin{array}{c}\text { Number of legislative elections } \\
\text { Number of cabinet changes } \\
\text { Guerrila warfare }\end{array}$ & $\begin{array}{c}\text { Riots } \\
\begin{array}{c}\text { Annual number of anti-government } \\
\text { demostrations }\end{array}\end{array}$ \\
\hline Canada & $\begin{array}{l}\text { Voice and accountability } \\
\text { Regulatory Quality } \\
\text { Rule of Law } \\
\text { Control of corruption } \\
\text { Government effectiveness }\end{array}$ & $\begin{array}{c}\text { CPI index of corruption } \\
\text { Purges }\end{array}$ & $\begin{array}{l}\text { Number of terrorist incidents per year } \\
\text { Number of victims per incident }\end{array}$ & $\begin{array}{l}\text { Number of legislative elections } \\
\text { Number of cabinet changes }\end{array}$ & $\begin{array}{c}\text { Annual number of anti-government } \\
\text { demostrations } \\
\text { Riots }\end{array}$ \\
\hline Denmark & $\begin{array}{c}\text { Government effectiveness } \\
\text { Rule of Law }\end{array}$ & $\begin{array}{l}\text { Control of corruption } \\
\text { CPI index of corruption }\end{array}$ & $\begin{array}{c}\text { Number of terrorist incidents per year } \\
\text { Number of victims per incident }\end{array}$ & $\begin{array}{c}\text { Number of cabinet changes } \\
\text { Number of legislative elections } \\
\text { Government crises }\end{array}$ & $\begin{array}{c}\text { Annual number of anti-government } \\
\text { demostrations } \\
\text { Riots }\end{array}$ \\
\hline Finland & $\begin{array}{c}\text { Government effectiveness } \\
\text { Regulatory Quality } \\
\text { Rule of Law } \\
\text { CPI index of corruption } \\
\text { Civil liberties } \\
\text { Political rights index }\end{array}$ & $\begin{array}{c}\text { Control of corruption } \\
\text { Voice and accountability }\end{array}$ & $\begin{array}{l}\text { Number of terrorist incidents per year } \\
\text { Number of victims per incident }\end{array}$ & $\begin{array}{l}\text { Annual number of anti-government de- } \\
\text { mostrations } \\
\text { Number of legislative elections }\end{array}$ & \\
\hline France & $\begin{array}{c}\text { Rule of Law } \\
\text { Voice and accountability } \\
\text { Government crises }\end{array}$ & $\begin{array}{l}\text { Regulatory Quality } \\
\text { Civil liberties } \\
\text { Control of corruption }\end{array}$ & $\begin{array}{c}\text { Number of terrorist incidents per year } \\
\text { Number of victims per incident }\end{array}$ & $\begin{array}{c}\text { Number of cabinet changes } \\
\text { Number of legislative elections }\end{array}$ & $\begin{array}{c}\text { Annual number of anti-government } \\
\text { demostrations } \\
\text { Assassinations }\end{array}$ \\
\hline Germany & $\begin{array}{l}\text { Government effectiveness } \\
\text { Regulatory Quality } \\
\text { Voice and accountability } \\
\text { Civil liberties }\end{array}$ & $\begin{array}{l}\text { Control of corruption } \\
\text { Rule of Law } \\
\text { CPI index of corruption }\end{array}$ & & $\begin{array}{l}\text { Number of constitutional changes } \\
\text { Number of cabinet changes } \\
\text { Number of legislative elections }\end{array}$ & $\begin{array}{l}\text { Revolutions } \\
\text { Strikes } \\
\text { Riots }\end{array}$ \\
\hline Greece & $\begin{array}{l}\text { Legislative Effectiveness } \\
\text { Civil liberties }\end{array}$ & $\begin{array}{l}\text { Voice and accountability } \\
\text { Control of corruption }\end{array}$ & $\begin{array}{l}\text { Number of terrorist incidents per year } \\
\text { Number of victims per incident }\end{array}$ & $\begin{array}{l}\text { Number of legislative elections } \\
\text { Number of cabinet changes }\end{array}$ & $\begin{array}{c}\text { Riots } \\
\text { Annual number of anti-government } \\
\text { demostrations }\end{array}$ \\
\hline
\end{tabular}




\begin{tabular}{|c|c|c|c|c|c|}
\hline & $\begin{array}{l}\text { Political rights index } \\
\text { Purges }\end{array}$ & $\begin{array}{l}\text { Government effectiveness } \\
\text { CPI index of corruption }\end{array}$ & & & Strikes \\
\hline Ireland & $\begin{array}{l}\text { Rule of Law } \\
\text { Government effectiveness } \\
\text { Regulatory Quality }\end{array}$ & $\begin{array}{l}\text { CPI index of corruption } \\
\text { Control of corruption }\end{array}$ & $\begin{array}{c}\text { Assassinations } \\
\text { Number of terrorist incidents per year } \\
\text { Number of victims per incident }\end{array}$ & $\begin{array}{c}\text { Number of cabinet changes } \\
\text { Number of legislative elections }\end{array}$ & $\begin{array}{c}\text { Annual number of anti-government } \\
\text { demostrations } \\
\text { Government crises }\end{array}$ \\
\hline Italy & $\begin{array}{c}\text { Rule of Law } \\
\text { Government effectiveness } \\
\text { Voice and accountability }\end{array}$ & $\begin{array}{l}\text { CPI index of corruption } \\
\text { Regulatory Quality }\end{array}$ & $\begin{array}{c}\text { Revolutions } \\
\text { Assassinations } \\
\text { Number of terrorist incidents per year }\end{array}$ & $\begin{array}{l}\text { Number of cabinet changes } \\
\text { Government crises } \\
\text { Number of legislative elections }\end{array}$ & $\begin{array}{c}\text { Riots } \\
\text { Annual number of anti-government } \\
\text { demostrations } \\
\text { Purges }\end{array}$ \\
\hline Japan & $\begin{array}{l}\text { Regulatory Quality } \\
\text { Government effectiveness } \\
\text { Voice and accountability }\end{array}$ & $\begin{array}{l}\text { Control of corruption } \\
\text { CPI index of corruption } \\
\text { Civil liberties }\end{array}$ & $\begin{array}{l}\text { Assassinations } \\
\text { Number of victims per incident }\end{array}$ & Number of legislative elections & $\begin{array}{c}\text { Strikes } \\
\text { Guerrila warfare } \\
\text { Annual number of anti-government } \\
\text { demostrations } \\
\text { Riots }\end{array}$ \\
\hline Netherlands & $\begin{array}{l}\text { Government effectiveness } \\
\text { Rule of Law } \\
\text { Voice and accountability }\end{array}$ & $\begin{array}{l}\text { Regulatory Quality } \\
\text { Control of corruption } \\
\text { CPI index of corruption }\end{array}$ & $\begin{array}{l}\text { Number of terrorist incidents per year } \\
\text { Number of victims per incident }\end{array}$ & $\begin{array}{c}\text { Number of legislative elections } \\
\text { Number of cabinet changes } \\
\text { Government crises }\end{array}$ & $\begin{array}{c}\text { Annual number of anti-government } \\
\text { demostrations } \\
\text { Riots }\end{array}$ \\
\hline Portugal & $\begin{array}{l}\text { Voice and accountability } \\
\text { Rule of Law } \\
\text { Regulatory Quality } \\
\text { Government effectiveness }\end{array}$ & $\begin{array}{l}\text { Control of corruption } \\
\text { Coups D'etat } \\
\text { Purges }\end{array}$ & $\begin{array}{c}\text { Number of terrorist incidents per year } \\
\text { Number of victims per incident } \\
\text { Assassinations }\end{array}$ & $\begin{array}{c}\text { Legislative Effectiveness } \\
\text { Number of legislative elections }\end{array}$ & $\begin{array}{c}\text { Political rights index } \\
\text { Annual number of anti-government } \\
\text { demostrations } \\
\text { Riots } \\
\text { Government crises }\end{array}$ \\
\hline Spain & $\begin{array}{l}\text { Legislative Effectiveness } \\
\text { Civil liberties } \\
\text { Voice and accountability } \\
\text { Rule of Law } \\
\text { Government effectiveness }\end{array}$ & $\begin{array}{l}\text { Political rights index } \\
\text { Control of corruption } \\
\text { Regulatory Quality }\end{array}$ & $\begin{array}{l}\text { Revolutions } \\
\text { Number of victims per incident } \\
\text { Assassinations }\end{array}$ & $\begin{array}{l}\text { Number of cabinet changes } \\
\text { Number of legislative elections }\end{array}$ & $\begin{array}{l}\text { Purges } \\
\text { Strikes }\end{array}$ \\
\hline Sweden & $\begin{array}{c}\text { Regulatory Quality } \\
\text { Rule of Law } \\
\text { Government crises } \\
\text { Government effectiveness }\end{array}$ & $\begin{array}{l}\text { Voice and accountability } \\
\text { CPI index of corruption } \\
\text { Control of corruption }\end{array}$ & $\begin{array}{c}\text { Number of terrorist incidents per year } \\
\text { Number of victims per incident } \\
\text { Assassinations }\end{array}$ & $\begin{array}{c}\text { Number of cabinet changes } \\
\text { Number of legislative elections } \\
\text { Number of constitutional changes }\end{array}$ & $\begin{array}{c}\text { Strikes } \\
\begin{array}{c}\text { Annual number of anti-government } \\
\text { demostrations }\end{array}\end{array}$ \\
\hline United Kingdom & $\begin{array}{l}\text { Government effectiveness } \\
\text { Regulatory Quality } \\
\text { Voice and accountability }\end{array}$ & $\begin{array}{l}\text { Control of corruption } \\
\text { CPI index of corruption }\end{array}$ & $\begin{array}{c}\text { Revolutions } \\
\text { Guerrila warfare } \\
\text { Number of terrorist incidents per year } \\
\text { Number of victims per incident }\end{array}$ & $\begin{array}{l}\text { Number of legislative elections } \\
\text { Number of cabinet changes } \\
\text { Government crises }\end{array}$ & $\begin{array}{c}\text { Riots } \\
\text { Assassinations } \\
\text { Annual number of anti-government } \\
\text { demostrations } \\
\text { Strikes }\end{array}$ \\
\hline United States & $\begin{array}{c}\text { Voice and accountability } \\
\text { Government effectiveness } \\
\text { Rule of Law } \\
\text { Regulatory Quality }\end{array}$ & $\begin{array}{l}\text { CPI index of corruption } \\
\text { Control of corruption }\end{array}$ & $\begin{array}{c}\text { Guerrila warfare } \\
\text { Number of terrorist incidents per year } \\
\text { Number of victims per incident }\end{array}$ & $\begin{array}{c}\text { Number of cabinet changes } \\
\text { Number of legislative elections } \\
\text { Government crises }\end{array}$ & $\begin{array}{c}\text { Strikes } \\
\text { Riots } \\
\text { Annual number of anti-government } \\
\text { demostrations } \\
\text { Assassinations }\end{array}$ \\
\hline
\end{tabular}

